\title{
Print Culture in Sundanese for 100 Years in the Dutch East Indies
}

\author{
Mikihiro Moriyama \\ Nanzan University, Japan \\ moriyama@nanzan-u.ac.jp
}

How to cite (in APA Style): Moriyama, M. (2018). Print culture in Sundanese for 100 years in the Dutch East Indies. Jurnal Pendidikan Bahasa dan Sastra, 18(1), 1-15. doi: 10.17509/bs_jpbsp.v18i1.12142

Article History: Received (January 18, 2018); Revised (February 15, 2018); Accepted (March 28, 2018).

Journal homepage: http://ejournal.upi.edu./index.php/BS_JPBSP

\begin{abstract}
Sundanese books have been printed since 1850 up to the present. This article tries to draw a configuration of printing books in Sundanese for about 100 years in the Dutch colonial and Japanese occupation period. Printing and publishing books in Sundanese was initiated by the Dutch colonial government for the sake of management of their colony. This article discuss three aspects in print culture in Sundanese: (1) the role of government printing house and private publishers; (2) the cultural relationship between manuscript and printed books, and; (3) the changes after the emergence of printed books. Print culture in the Sundanese-speaking community was born and has developed. Its facets have changed from time to time. We notice more than 2200 Sundanese books were published up to the second decade of the $21^{\text {st }}$ century when the technological innovation has proceeded in an enormous pace. However, the importance of Sundanese publication has not diminished in terms of nurturing educated citizens in this digital-oriented society and supporting cultural identity.
\end{abstract}

Keywords: print culture, printing books, Sundanese, Sundanese-speaking community.

\section{Budaya Cetak dalam Bahasa Sunda selama 100 Tahun di Hindia Belanda}

\begin{abstract}
Abstrak: Buku-buku bahasa Sunda telah dicetak sejak 1850 hingga kini. Artikel ini mencoba untuk menggambarkan konfigurasi buku cetak dalam bahasa Sunda selama sekitar 100 tahun di masa penjajahan Belanda dan pendudukan Jepang. Percetakan dan penerbitan buku dalam bahasa Sunda diprakarsai oleh pemerintah kolonial Belanda demi pengelolaan koloni mereka. Artikel ini membahas tiga aspek dalam budaya cetak dalam bahasa Sunda: (1) peran percetakan pemerintah dan penerbit swasta; (2) hubungan budaya antara naskah dan buku cetak, dan; (3) perubahan setelah munculnya buku cetak. Budaya cetak dalam komunitas berbahasa Sunda lahir dan berkembang. Aspek-aspeknya terus berubah dari waktu ke waktu. Kami mencatat lebih dari 2200 buku bahasa Sunda diterbitkan hingga dekade kedua abad ke-21 ketika inovasi teknologi telah berjalan dalam kecepatan yang sangat besar. Namun, pentingnya publikasi bahasa Sunda tidak berkurang dalam hal memelihara warga negara terdidik dalam hal orientasi masyarakat digital serta mendukung identitas budaya.
\end{abstract}

Kata kunci: Budaya cetak, buku cetak, bahasa Sunda, komunitas penutur bahasa Sunda. 


\section{INTRODUCTION ${ }^{1}$}

Sundanese books have been printed since 1850 up to the present. This article tries to draw a configuration of printing books in Sundanese for about 100 years in the Dutch colonial and Japanese occupation period. Printing and publishing books in Sundanese was initiated by the Dutch colonial government for the sake of management of their colony. Schools and books were prepared to educate the 'indigenous people' to supply government local officials. In the beginning of the $20^{\text {th }}$ century publishing books were institutionalized into Commissie voor de Inlandsche School- en Volkslectuur (Committee for Indigenous Schoolbooks and Popular Reading Books), a governmentsubsidised institution that was to provide the growing number of literates in the Indies with 'good' and 'appropriate' reading materials in 1908. This institution became Balé Poestaka in 1917, which continued to publish Sundanese and other local languages. Besides the colonial government's publishing, there were a certain number of printed books published by local publishers.

In this article ${ }^{1}, \mathrm{I}$ try to discuss the next three aspects in print culture in Sundanese: (1) the role of government printing house and private publishers, (2) the cultural relationship between manuscript and printed books (3) the changes after the emergence of printed books. At the same time this article suggests how important print culture including consideration of literature and language is to nurture educated citizens in this digitaloriented society, especially in Indonesia.

\section{Printing Sundanese Books For 100 Years}

The first book printed on Java was a Dutch one, in the middle of the 17th century. Not until the middle of the 18th century were books printed in local languages, first in Malay, the language of communication in the Archipelago, then in Javanese, the main language of Java and central to Dutch activities. It would be another hundred years before the first Sundanese books began to appear (AVSS, 1853, p.320-367). The number of printed books in Sundanese - mainly schoolbooks - was to remain relatively small. No wonder the most productive Sundanese author in the second half of the 19th century, Moehamad Moesa, lamented:

basa Soenda noe kalipoet,

(Sundanese has been concealed,)

tanda jén kalipoetan,

(The sign that it is concealed is,)

boektina di Soenda sepi,

(that Sunda is desolate,)

hanteu aja boekoe woengkoel basa

Soenda, (no book was written in

Sundanese only.)

Reja maké doewa basa,

(Many of them use two languages.)

njaéta salah-sabidji,

(Namely one of these, )

Malajoe atawa Djawa.

(Malay or Javanese.)

(Moesa, 1867, p. 5)

Sundanese was given less attention by the government than Javanese. Malay and Javanese were seen as more important languages and given a higher priority until the end of the colonial era. Sundanese lived in a valley between two high mountains, Javanese and Malay', as Moesa chanted (Moesa, 1867,p. 5).

Beginning with the first book, Kitab Pangadjaran Basa Soenda (Sundanese Language Textbook), printed in 1849 or 1850 in Holland, and ending with the declaration of Independence of Republic of Indonesia in 1945, we will take stock of printed Sundanese books; they will be counted as long as they were in Sundanese. ${ }^{3}$

Between 1850 and 1945, I found reference to about 640 books printed in Sundanese: they were printed by the government printing house Landsdrukkerij (Dutch state-owned printing house), 
Committee for Indigenous Schoolbooks and Popular Reading Books which became Balé Poestaka, missionary presses, European/Eurasian private printing houses, and indigenous printing houses. ${ }^{4}$

\section{Government printing house and publisher}

The most significant role was played by the government publishers for the Sundanese publication for 100 years judging from the number of publication. It seems that 90 percent of the publications are published by Landsdruk.kerij, Committee for Indigenous Schoolbooks and Popular Reading Books, and Balé Poestaka. The government enterprise of the Landsdrukkerij printed and published about 150 books and Balé Poestaka published about 400 books including the publications of the former institution Committee for Indigenous Schoolbooks and Popular Reading Books.

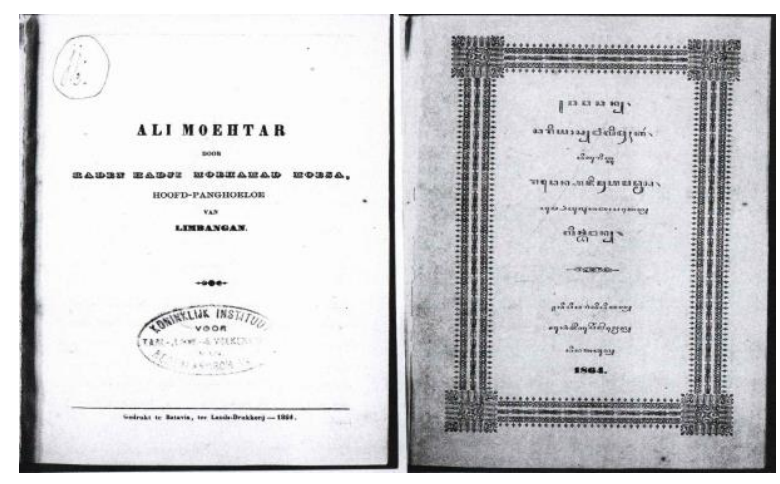

Figure 1. An early printed Sundanese book

The Landsdrukkerij played an extremely important role in the 19th-century book market on Java. It had been made a governmental institution in 1809 by Governor-General Herman Willem Daendels (1808-1811). This government printing house transferred its significant role to the Committee for Indigenous Schoolbooks and Popular Reading Books after 1908, at least in printing indigenous publications. The Committee, headed by G.A.J. Hazeu, the Adviser for Native Affairs, was installed by government decree in September 1908 (Jedamski, 1992, p. 25). The duty of the Committee was to 'memberi pertimbangan kepada
Direkteur Onderwijs dalam hal memilih karangankarangan jang baik untuk dipakai disekolahsekolah dan untuk didjadikan batjaan rakjat' (advise the Director of Education in the selection of good writings to be used at schools and to be designated reading materials for the people) (Balai Pustaka [1948], p.6). In 1913 D.A. Rinkes succeeded Hazeu as head of the Committee, and in 1917 the independent Bureau, which became detached from the Office of the Adviser for Native Affairs, was established under the name Balai Poestaka. In that same year Rinkes became the first Director of the Bureau. Under the guidance of the director, Balai Poestakastarted to streamline its management to assist the colonial government in influencing the public discourse conducted in vernacular languages in the colony. Javanese, Sundanese, Malay and Madurese editorial boards were set up, and D.K. Ardiwinata, the author of the first Sundanese novel, was appointed chief editor for the Sundanese section. Sundanese writings were examined and selected according to the judgement of the Bureau. In 1918 all phases of publication were undertaken by the institute, and in 1924 its building was moved to the old Landsdrukkerij site for the sake of rationalisation.

The Balai Poestaka played a significant role in print culture in the first half of the $20^{\text {th }}$ century. For instance, it published 236 books between 1911 and 1916: 117 books in Javanese (49\%), 68 in Sundanese (29\%), 33 in Malay $(14 \%)$ and 18 in Madurese $(8 \%)$ (Balai Pustaka 1948: 9). As mentioned above, the total number of Sundanese books had reached about 400 up to $1945^{5}$. It is deemed that Balai Pustaka had an enormous impact to nurture print culture in Sundanese even though the contents were selected and a kind of censorship had worked in a sense.

\section{Private printing houses and publishers}

It seems that up to the early 20th century, a market economy in the publishing business did not exist. Printing Sundanese books did not make money because there was little 
readership for books. Furthermore, most of the printed books were in Roman script and literacy in that script was severely limited. Printing presses were also rare and expensive.

The situation did seem to have changed by the 1920s. Local entrepreneurs began to participate in the publishing business, and the population growth in the Indies and the increases in literacy may have supported their businesses. Added to this, the increasing availability of printing presses and article cannot be overlooked. The conditions for a publishing business were gradually formed, books became a commodity in the Indies, and publishers found opportunities to make a profit from printed books in Sundanese.

There were two types of private printing houses. One is the Dutch or Eurasian and some Chinese capital printing house $^{6}$ which received printing orders from Balai Poestaka. Another is the indigenous printing house - small and 'wild' (liar), difficult to be put under the control of the colonial government. Through the former private printing houses, the Sundanese titles were published under the name Volkslectuur. Serie uitgaven door bemiddeling der Commissie voor de Volkslectuur (A Series of Publications by the Committee for Popular Reading Books), which was printed on the title page. Most of these printing houses withdrew by degrees from the business of printing Sundanese books, especially since Balai Poestaka itself tried to monopolise the publishing market and stopped sending printing orders under the policy of director Rinkes.

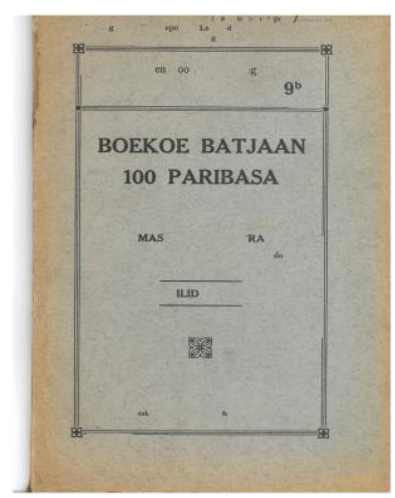

Figure 2. The cover page of a Sundanese book published by Balai Poestaka

Meanwhile, the 'wild' printing houses sprang up like bamboo shoots after rain (Moriyama 1990: 115-116). Sundanese books printed by such small printing houses increased remarkably beginning in the second decade of the 20th century. Most of them were in Bandung: they were Toko Boekoe M.I. Prawira-Winata, N.V. Sie Dhian Ho, Insulinde, Sindang Djaja, H.M. Affandi, Dachlan-Bekti, Kaoem Moeda, Nanie, and Toko Boekoe Union. Meanwhile, a couple of publishers were in other cities in West Java: they were Toko Boekoe Pasoendan in Tasikmalaya, Toko Boekoe M. Engka Widjaja in Garut, and Toko Boekoe Boerhan in Cirebon. In terms of legibility and article quality, their publications were usually inferior to those issued by Balai Poestakaand the distribution was not as good, but the books were cheaper. Compared with Balai Poestaka's books, the contents were less moralistic, the language less artificial and the stories more exciting and nationalistic so that they were loved much by the people (Kartini, 1979, p. 810, p.61-63).

We also need to bear in mind that these printing houses were responsible not only for printing books but also sometimes for compiling and editing them. There was no clear distinction between printing house and publisher. If they call 'Toko Boekoe'(book shop), it published a book and very often sold it. For instance, a well-known one in Bandung in the 1920s Toko Boekoe M.I. PrawiraWinata. This publisher used to edit a draft and order a printing house, mostly to N.V. 
Boekh. Visser \& Co., to print the draft. The number of impression was mostly 2,500 copies each title and the total number of titles were at least fifteen. Usually editing was conducted by the owner M.I. Prawira Winata by himself. He was a chief teacher of Lengkong district in Bandung. The printed books were sold for 1 to 1.25 Dutch guilders each and sent by post for 0.25 Dutch guilders by the business. The cover page of a book in front and back lists all publications of the publisher for sale. Meanwhile, another book shop had its own printing machine so that the business edited, printed and sold books by themselves. A good example was Drukkerij 'Dachlan - Bekti' at a street of Groote Postweg 23 Bandung. One of the titles published by this business, Carios Agan Permas (Tale of Madam Permas) authored by Joehana and published in 1926, became well-known (Kartini, 1979, p. 4-17).

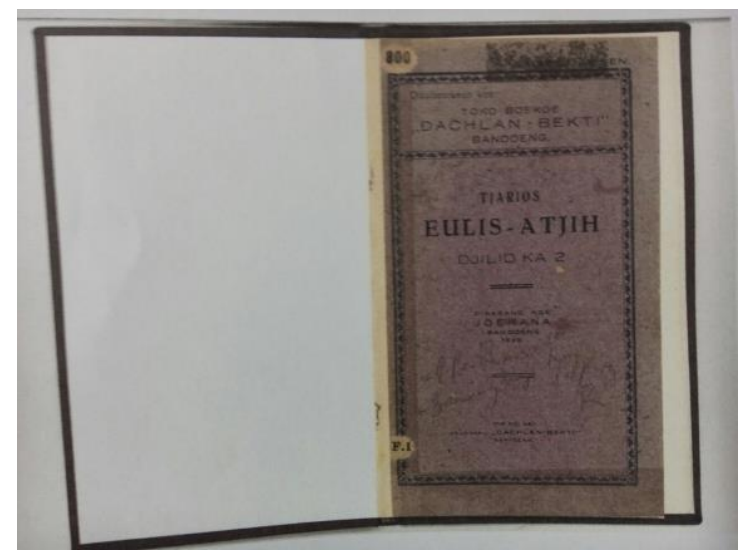

Figure 3: Tjarios Eulis - Atjih published by Dachlan - Bekti in 1925

The authorities tried to control local printing houses for the sake of order and peace in the colony mainly through Balai Poestaka, but this was not an easy task. The books were printed everywhere and circulated directly according to consumer demand. The context of Sundanese writing started to change, becoming freer, more secular and more dynamic than ever before. However, the number of books were far fewer than ones published by Balé Poestaka.

\section{Scripts used for the printed books}

Three scripts were used for Sundanese publications: Javanese, ${ }^{8}$ Roman and Arabic (called Pegon by the Sundanese). In the beginning of printing a considerable number of books were printed in Javanese script because of K.F. Holle's idea that Javanese script was preferable for printing Sundanese books, given the kind of literacy of the potential readers. On the other hand, Arabic script was never suggested because of the fear of 'Islamic fanaticism'.

As time went by, fewer and fewer books (and fewer total pages) were printed in Javanese script, and more printed in the Roman script. Apart from ideological reasons - the Roman script was associated with modernity - there were also economic ones: Javanese script needed double the space of the Roman script. ${ }^{9}$ In the early period, 11 dual-script books were published, the right page in Roman script, the left page in Javanese script in a two-page spread. This type of book gradually disappeared because of the high cost of printing (Moriyama 1995: 451452). After 1902 the Landsdrukkerij no longer published Sundanese books in Javanese script, except for some reprints.

Missionaries developed their own ideas about locally used scripts. The Dutch Missionary Society (NZV) printed all their publications in Roman script. Meanwhile, another missionary the Netherlands Bible Society (NBG) in Amsterdam published three books in Arabic script, translations of the Bible and the Gospel, prepared by S. Coolsma, who, more than any other Dutchman, was aware of the fact that Arabic script was better known than Javanese script among the Sundanese and only members of the elite read Javanese script. However, even in this more familiar script, the efforts to proselytise were doomed to failure.

In fact, the government was not completely unaware of Sundanese familiarity with the Arabic script, witness Wawatjan Piwoelang Panoelak Panjakit Kolera (Wawacan 
Teaching the Prevention of Cholera), which was published in Arabic script in an apparent effort to reach as many readers as possible. ${ }^{10}$ So-called Arabic literacy did not vanish but developed parallel with the growth of Roman literacy; up until the present day, Arabic script is used and sometimes also printed in the Sundanese-speaking areas, especially in and around Islamic institutions. On the other hand, Javanese script has completely vanished in these areas.

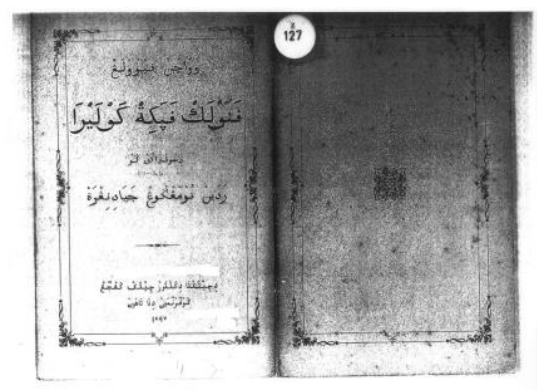

Figure 4. Wawatjan Piwoelang Panoelak Panjakit Kolera published in 1905

\section{Printing techniques}

Two printing techniques were used for the production of Sundanese books: lithography and typography. Lithography is best seen as an extension or variation of the traditional way of producing manuscripts. It is not clear how widely this technique was used in the Sundanese-speaking community, and almost all of the lithographs that have been preserved (seven) were produced on Sayyid 'Uthmân's machine in Arabic script - but then, we do not know how many lithographs were used in institutions of Muslim education.

Typographic techniques were used to print books in all three scripts, although those in Arabic script are very few. Typographically produced texts were radically different from manuscripts, in form as well as in distribution. When people read a manuscript, they could see evidence of the human hand and perhaps hear the human voice between the lines of the page. Typography, on the contrary, gave the touch of a machine, a wonderful and overwhelming, but cold feeling.

The Sundanese community had a tradition of manuscript reading. This tradition did not vanish after the emergence of mechanically printed books, but changes did occur in the reading activities.

Mechanical reproduction had newness: each book has the same shape in appearance and the exact same type-letters on its pages instead of the wild variety of manuscripts. Uniformity through printing confirmed the tendencies towards strengthening the unity of the language community, it seems. Moreover, people began to share tastes in and knowledge of writing, and thus became a new community of sorts. New cultural practices of reading and writing emerged, creating fresh patterns of solidarity and belonging in which the authority of manuscripts began to be questioned - and manuscript culture could wither. However, its process went not so quickly in the Sundanesespeaking community. For the time being, the two different types of medium continued to be produced and read in parallel. In other words, printing did not spell the end of the manuscript culture.

Moreover, printed materials and also European type of schools stimulated reading activities in the indigenous communities. Schools certainly created more literate people and printed materials indirectly affected the notion of reading. More people became interested in reading activities, it seems. Witness is that a number of manuscripts were produced during this period as Ekadjati's inventory tells us (Ekadjati 1988). It means that manuscripts were newly created and the old ones were still copied. ${ }^{11}$ In parallel, some traditional narrative poetry, wawacan, that were circulating in manuscript were to be printed in the first decade of the 20th century, like Wawacan Angling Darma (The Story of Angling Darma). A traditional work, it was published under the author's name of Martanegara in 1906 by a private firm in Bandung, Toko Tjitak Afandi. This example suggests that the 
popularity of wawacan and its poetic form dangding lasted long among the Sundanese as we discuss in the next section.

\section{CHANGES AFTER EMERGENCE OF PRINTED BOOKS}

Print literacy was being formed alongside a manuscript literacy as we have seen in the previous section. Some works were read in manuscript and others were read separately in print. ${ }^{12}$ Readers did not stop consuming manuscripts that had distinct cultural meanings, a distinct 'aura' that could not be replaced by printed books. Still, those who had read manuscripts in the past were the same people who were starting to read printed books too. As the number of schools increased, so did the number of printed books, and the circle of those who acquired a print literacy became wider. Print literacy was to constitute the basis for a modern readership, introducing innovations and alterations in the configuration of Sundanese writing. We will see changes in terms of form of writing in Sundanese after the print literacy grew below.

\section{Prose and the emergence of novel}

When printing was introduced into Sundanese writing in the middle of the 19th century, dangding, a traditional poetry, was so much loved by the Sundanese that Dutch scholars concluded that it was the 'most traditional' and the 'most prestigious' form of Sundanese writing and the most favourable means for education. As a result, dangding was given a prominent place in the educational materials that were produced by the colonial authorities.

One of the most knowledgeable missionary on Sundanese writing Coolsma believed that prose should be developed among the Sundanese because it would embody the novelties of modernity (Coolsma, 1881, p.145). A Sundanese lady, a daughter of the well-known Sundanese writer Moehamad Moesa ${ }^{13}$, made some intriguing remarks on prose and reading. In the preface to her compilation of translated stories, Lenggang Kantjana used the word omongan to mean prose (Lenggang Kantjana, 1887, p.1-2). At the traditional community reading was usually voiced, done by intoning or reciting and shared activities by the people. Lenggang Kantjana may have been the first to express in writing that reading could be done by oneself, for oneself, perhaps even in silence. Tales were baris aoseun diilo, 'something to be read for yourself, she suggests, diilo referring to reading alone or with a soft voice and skimming over (Coolsma, 1913, p.240). ${ }^{14}$ Reading a book could be a personal, silent activity that Sundanese readers could do lying on a bed or sitting in a rocking chair, just as the Europeans did according to this Sundanese lady. Here we see the emergence of modern reader in the Sundanese-speaking community. At the same time the new reading practice asserted its influence on the form of writing too.

The prose gave birth a new genre. In 1914 the first Sundanese novel, Baruang Ka Nu Ngarora (Poison For The Youth), was published. D.K. Ardiwinata, a chief editor for the Sundanese section in the abovementioned Committee, may be identified as the author, although the title page of the first volume does not mention his name. ${ }^{15}$ The setting of this novel is quite individual, being different from a passage like 'once upon a time, there was a kingdom', as in traditional writing. The monologue of passers-by is in everyday style. The description is realistic in terms of the setting and characters, and they are individualistic at the same time. This individualisation can be considered the representation of the 'modern self' as a feature of modern literature. ${ }^{16}$ This realism cannot be found as such in traditional Sundanese writings such as wawacan. Gradually but steadily, the novel began to push aside wawacan and other genres and became a prominent form of writing in the first half of the twentieth century. 


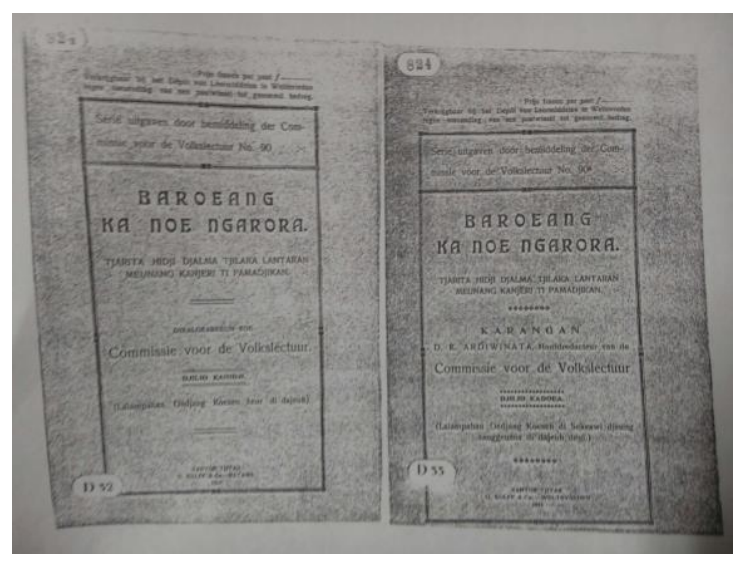

Figure 5. The first Sundanese novel, Baroeang Ka Noe Ngarora published in 1914.

\section{New wawacan and gradual vanishing}

In his book on early 20th-century Sundanese writing, van den Berge, for one, has shown us that one of the most authoritative magazines of Sundanese culture in the 1930s, Parabiangan, ${ }^{17}$ featured a dangding, traditional poetry, on the third page of each issue (the most significant page after the front page) dealing with passion, fate, the monarch, nature or culture (Berge, 1993, p.79-80). Another witness of the prominent position of poetry is Soewarsih Djojopoespito, a modern Sundanese author who foregrounds the soothing qualities of poems in a conversation between the young man, Sutrisna, and the young lady, Maryanah, in a novel she wrote in 1937: ${ }^{18}$

'For me books are like good friends', said Sutrisna, while he let the ash of his cigarette fall into an ashtray. When we are sad or looking for the way in life, how great is the help of books! When we are happy, we can enjoy nothing more than reading guguritan; when we are in misery, we feel we are getting medicine for our sadness from reading something that shows there are still many things that bring more difficulties than ones we have. And also, when we are looking for the right way, books often guide us into the right direction.' Maryanah agreed and answered: 'You mean the right way? $[\ldots] . '$
'Keur abdi mah sobat dalit buku teh', tjeuk Sutrisna, bari ngeprukkeun sekar rokok kana asbak. 'Geuning ari urang keur sedih atanapi keur milari djalan hirup, sakitu agengna pitulung buku-buku teh. Dina keur bungah tiasa ngahenang-ngahening, maos guguritan, dina keur larana asa kaubaran kasedihan teh, komo upami maos, perkawis nu mintonkeun jen seueur keneh anu langkung ti urang waluratna mab! Sareng deui, upami milari pangdjeudjeuh lakulampah, buku teh sok nungtun urang kana pimendakeunnana.' Marjanah unggeuk, bari ngawalon: 'Pangdjeudjeuh laku lampah urang? [...]' (Djojopoespito, 1959, p.74).

Djojopoespito seems to tell us in the 1930s that young people are still reading guguritan, another genre of traditional poetry from wawacan but still in the same form of poem dangding, in search of the meaning of life. Colonial authorities were of the same opinion, as evidenced by the remarks of Hidding, then Director of Balai Poestaka:

Indeed, next to fairytales in prose and the above-mentioned pantun stories, most sagas, legends and traditional stories are composed in tembang, that is to say they are composed in a variety of pupuh in accordance with the contents of the story; such a compilation is called wawacan. This wawacan encompasses myths as well as historical narratives (babad), Muslim-saint legends and also fairytale-like narratives derived from wayang. This [genre] wawacan is the main representative of Sundanese literature, which indisputably at present still occupies the first place.

Immers naast de in proza verhaalde
sprookjes en de bovengenoemde
pantoenverhalen zijn de meeste sagen,
legenden, overleveringen en dgl. in tembang
opgesteld, d.w.z. dat zij een naar den
inhoud van het verhaalde afwisselende reeks
poepoeh's vormen, die met elkaar wawatjan
heeten. En deze wawatjan omvat roowel
mythen als ook geschiedenisverhalen
(babad), Mohammedaansche
heiligenlegenden en aan de wajang ontleende


sprookjesachtige vertellingen. Deze wawatjan is de voornaamste representant van de Soendaneesche literatuur, die ook nu nog altijd onbetwist de eerste plaats inneemt (Hidding, 1935, p. 128).

Wawacan, in short, was still loved by the people in the 1930s - and not only myths, historical narratives and wayang stories were composed in wawacan, but also experiences from daily life were told in the traditional poetry according to the Director of Balai Poestaka. Thirty years later, Ajip Rosidi pointed out that the 'new' wawacan emerged in the 1930s:

What was told in the form of wawacan was no longer only stories of kings, princesses and supernaturally powerful priests, but also the daily life of the writer's time.

Jang ditjeritakan dalam bentuk wawatjanwawatjan itu bukan lagi banja bikajatbikajat tentang radja-radja dan putri-putri serta pendeta-pendeta sakti, melainkan djuga tentang penghidupan sehari-hari pada djaman pengarangnya sendiri (Rosidi, 1966, p.29).

Wawacan Enden Sari-banon, Carios Istri Rayungan (Wawacan of Lady Sari-banon, The Story of a Skittish Lady) by Memed Sastrahadiprawira published in 1923, Wawatjan Roesiab Noe Geulis (Wawacan the secret of the Beauty) in 1920s, and Wawacan noe Kaleungitan Caroge (Wawacan of One Who Lost a Husband) in 1931 are good examples of 'new' wawacan. ${ }^{19}$ The genre was changing in nature: realism infiltrated this so-called traditional form of writing. ${ }^{20}$ It is evident that the notions of wawacan were fundamentally changing and that a number of 'new' wawacan were published.

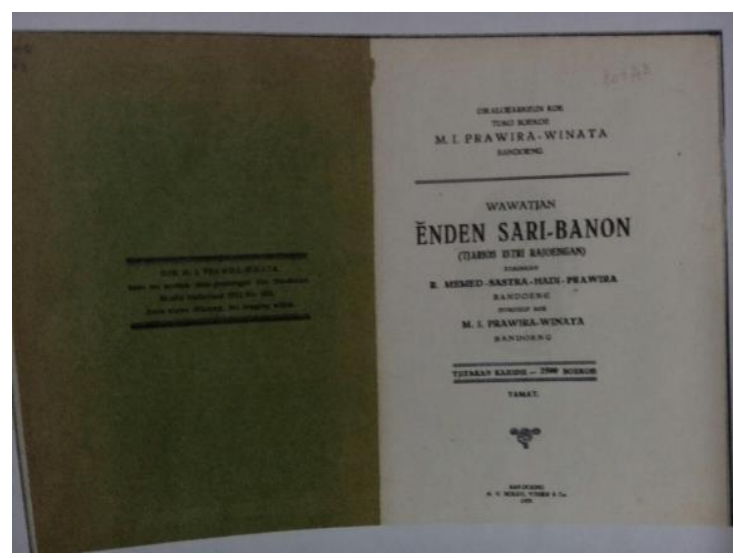

Figure 6. Wawacan Enden Sari-banon, Carios Istri Rayungan published in 1923

The flexibility of wawacan, however, became limited as modernity infiltrated into the Dutch East Indies' society in the early 20th century. Printing brought change of reading; reading aloud and singing became no absolute way of reading. Even silent reading was spreading in the communities gradually, it seems. The people was not only enjoying sound but also obtaining knowledge through reading books, especially school books. The beauty and artfulness in writing became less important than legibility and intelligibility that was provided by print technology. Therefore, ornamental and idiomatic expressions and clichés in the traditional poetry became unnecessary requirement for the Sundanese writing. Moreover, rules and metres in poetry were felt disturbing the progress of the story. The story written in realism and individualisation does not need any rules but 'freedom' as it will develop its way. Prose was gradually pushing wawacan and dangding to the margins of Sundanese writing after the end of the Dutch colonial period.

In an article in the Sundanese magazine Poesaka-Soenda in 1926, a writer using the pseudonym Goeroe (Teacher) predicted the demise of wawacan or stories composed in dangding ("tjarita-tjarita anoe digoerit') as follows:

Now times have changed, as we are experiencing. Stories that are composed in dangding have become few in number; what has emerged is 
free composition. ${ }^{21}$ Ideas coming from the west on various things have had enormous influence on Sundanese literature. Many books have been published. Principally they are translations of Dutch or old stories adapted to recent times so that they suit recent developments.

Ajeuna geus ganti djaman nja oerang anoe ngalaman. Tjarita-tjarita anoe digoeritbeuki lila beuki koerang; anoe madjoe karangan-karangan noe make basa diladjoer. Pikiran-pikiran anoe datang ti bangsa koelon tina roepa-roepa perkara, gede pisan pangaroebna kana kasoesastran Soenda. Pirang-pirang boekoe anoe kaloear, babakoena salinan tina basa Walanda atawa tjarita-tjarita koena beunang masieup, soepaja soeroep kana kadjadian-kadjadian kaajeunakeun (Goeroe, 1926, p. 4). ${ }^{22}$

The second and third decades of the 20th century witnessed a short and final boom in the publication of narrative poetry, traditional wawacan and 'new' wawacan; most of them were published by Balai Poestaka, only some by private publishers such as Toko Boekoe M.I. Prawira-Winata. The change of the configuration of Sundanese writing took place: the gradual vanishing of traditional poetry from literary life and the rise of the novel. ${ }^{23}$

\section{CONCLUSION}

In my books published in 2005 (Moriyama, 2005), I argued that printing technology and prose became a good match but wawacan was a mismatch with print. That is the reason why wawacan and traditional poetry has gradually withered. However, as a matter of factit is obvious from my further research that a number of wawacan had been produced not only by Balé Poestaka but also by indigenous publishers in West Java at least until the end of the Dutch colonial period. It is difficult to think that the main reason of demise of wawacan was the mismatch with print.

A possible reason of the demise was the form of writing itself. The form of writing, of course, interacted with and altered reading habits. Gradually people shared less often stories in the traditional, more or less ritualised way, and intoning or reciting was no longer the sole manner of 'reading a book'. Wawacan in both manuscript form and print had been read by the people. However, the traditional style of reading gradually did not suit with the modern readers in the Sundanese-speaking communities no matter what the materials were.

Another possible reason was the change of notion of literature. The idea of literature embraced by the people had changed by degrees as the community was becoming modern. The traditional literary works represented the transcendental of the world, meanwhile modern literary works represent real world around the people. ${ }^{24}$ The latter was good match with a new genre novel rather than traditional poetry.

Print culture in the Sundanesespeaking community was given birth and has developed. It's facets have changed from time to time. We notice more than 2200 Sundanese books were published up to the second decade of the $21^{\text {st }}$ century when the technological innovation has proceeded in an enormous pace. However, the importance of Sundanese publication has not diminished in terms of nurturing educated citizens in this digital-oriented society and supporting cultural identity.

\section{REFERENCES}

Anonymous. (1918). 'Schets van een Werkprogramma voor de Commissie voor deVolkslectuur', Vrijzinnig Weekblad, 26, p.425-428.

Anonymous. (1963) 'Het werk van de Commissie voor de Volkslectuur in Nederlandsch Indië, (Appendix to an official letter of the Minister of Colonial Affairs tot he Queen, 26 February 1926) in S.L. van der Wal, Het onderwijsbeleid in Nederlands-Indië 1900-1940, Groningen: n.p., 404-409. 
Ardiwinata, D.K.(1914). Baroeang Ka Noe Ngarora, Batavia: G. Kolff \& Co., Serie uitgaven door bemiddeling der Commissie voor de Volkslectuur No. 90 .

AVSS onder ultimo december 1852.(1853). Batavia: Landsdrukkerij.

Balai Pustaka.(1948). Balai Pustaka Sewadjarnja 1908-1942, Djakarta: Balai Pustaka.

Bataviaasch Genootschap van Kunsten en Wetenschappen.(1886). 'Bijlage VIII. Lijst der leden van het Genootschap op ultimo December 1885', Notulen van de Algemeene en Bestuurs-vergaderingen van het Bataviaasch Genootschap van Kunsten en Wetenschappen Deel XXIII:57-62.

Berge, T.van den.(1993). Van Kennis tot Kunst, Soendanese Poezie in de Koloniale Tijd, Ph.D. thesis, State Universiteit of Leiden.

Bureau voor de Volkslectuur (Balai Poestaka).(1924). Resultaten van de Volkslectuur in het jaar 1922, Batavia.

Chambert-Loir, H.(1991). 'Malay Literature in the 19th Century; The Fadli Connection', in J.J. Ras and S.O. Robson ed., Variation, Transformation and Meanig. Studies on Indonesian Literatures in Honour of $A$. Teeuw, pp. 87-114, Leiden: KITLV Press.

Chijs, J.A. van der.(1875). 'Proeve eener Ned. Indische Bibliographie (1659-1870)', Verbandelingen van het Bataviaasch Fenootschap van Kunsten en Wetenschappen, 17, p. 1-325.

-(1880). 'Proeve eener Ned. Indische Bibliographie (1659-1870), supplement I', Verbandelingen van het Bataviaasch Fenootschap van Kunsten en Wetenschappen 19: xxxix, 1-93

'Proeve eener Ned. Indische Bibliographie (1659-1870), supplement II', Verbandelingen van het Bataviaasch Fenoot-schap van Kunsten en Wetenschappen 55 (3): 1-64.

Colsma, S. (1881). West-Java. Het land, de bewoners en de Arbeid der Nederlandsche Zendingsvereeniging., Rotterdam: J.H. Dunk.

----1913). Soendaneesch-Hollandsch woordenboek, 3rd. edition, Lei-den: A.W. Sijthoff's UitgeversMaatschappij.

Commissie voor de Volkslectuur.(1912). Palanggeran Noeliskeun Basa Soenda koe Aksara Walanda. Batavia.

Departement van Gouvernementsbedrijven in Nederlandsch-Indië.(1912).

Landsdrukkerij Verslag over 1911, Batavia: Landsdrukkerij.

Djojopoespito, S. (1959). Marjanah, Djakarta: Balai Pustaka.

Ekadjati, E.S. (ed). (1988). Naskah Sunda: Inventarisasi dan Pencatatan. Bandung: Lembaga Penelitian Universitas Padjadjaran, Tokyo: The Toyota Foundation.

-.(1996). 'Cultural Plurality: The Sundanese in West Java', in lluminations by Ann Kumar and John H. McGlynn, Jakarta: The Lontar Foundation, New York and Tokyo: Weatherhill, Inc.

Eringa, F.S. (1984). Soendaas-Nederlands Woordenboek, (mede met gebruikmaking van eerder door R.A.Kern bijeengebrachte gegevens), Dordrecht, Cinnaminson: Foris Publications Holland.

Jedamski, D.(1992). 'Balai Pustaka: A Colonial Wolf in Sheep's Clothing', Archipel44, p. 23-46.

Encyclopaedie van Nederlandsch-Indië. (1917-1939). ${ }^{2 n d}$ edition. 4 vols and 4 suppliments. [s'-Gravenhage: Nijhoff, Leiden: Brill]. 
End, TH.van den. (1991). De Nederlandsche Zendingsvereeniging in West-Java 18581963. Een bronnenpublicatie., Leiden: Raad voor de Zending der Ned. Herv. Kerk, de zending der Gereformeerde Kerken in Nederland en de Gereformeerde Zendingsbond in de Ned. Herv. Kerk.

Faruk.(2002). Novel-novel Indonesia. Tradisi Balai Pustaka 1920-1942. Yogyakarta: Gama Media.

Goeroe.(1926). 'Kasoesastran Soenda', PoesakaSoenda 4 (1), pp. 11-16.

Hassert, J.M. van. (1938). 'Het kantoor voor de Volkslectuur',

Bibliotheekleven,23,pp.122-126.

Hidding, K.A.H.(1935). Gebruiken en Godsdienst der Soendaneezen. Batavia: G.Kolff \& Co.

Jedamski, D. (1992). 'Balai Pustaka: A Colonial Wolf in Sheep's Clothing', Archipel44, pp. 23-46.

Kantoor voor de Volkslectuur.(1931). Eenige Resultaten van de Arbeid in het jaar 1930, Batavia: Volkslectuur.

Kartini, T., Hadish, Y.K., Sumardipura, S.,\&Iskandarwassid.(1979). Yuhana Sastrawan Sunda. Jakarta: Pusat Pembinaan dan Pengembangan Bahasa, Departemen Pendidikan dan Kebudayaan.

Kimman, E. (1981). "Indonesian Publishing, Economic Organizations". Langganan Society, Hollandia Baarn.

Kitano, M.(1993). "Oranda Higashi Indo jidai no Peranakan kajin Bungaku no tanjo to hatten 1880-1924".M.A. thesis. Osaka University of Foreign Studies.

Karatani, K.(1993). Origins of Modern Japanese Literature. Durham and London: Duke University Press.
Lenggang Kantjana.(1887). Warnasari jilid III. Batavia: Landsdrukkerij.

Maier, H.M.J. (1993a). 'Boredom in Batavia: A Catalogue of Books in 1898', in: D.M. Roskies (ed.), Text/politics in Island Southeast Asia, Essays in Interpretation, pp. 131-156, Athens, Ohio: Ohio University Center for International Studies.

Moesa, M.(1867). Dongeng-dongeng Piêntêngên. Batavia: Landsdrukkerij.

Molen, W., van der.(2000). 'Hoe heeft zulks kunnen geschieden? Het begin van de Javaanse typografie', in: van der Molen Willem: Arps, Bernard (ed.), Woord en Scbrift in de Oost. De betekenis van zending en missie voor de studie van taal en literatuur in Zuidoost-Aqie, pp. 132162, Leiden: Opleiding Talen en Culturen van Zuidoost-Azie en Oceanie, Universiteit Leiden, Semaian 19.

Moriyama, M. (1990). 'The Sundanese Epic Wawacan in Print', Southeast Asian Studies 28 (1): 108-122.

-.(1995). 'Language policy in the Dutch colony: on Sundanese in the Dutch East Indies', Southeast Asian Studies 32 (4): 446-54.

-(2005). Sundanese Print Culture and Modernity in $19^{\text {th }}$ Century West Java. Singapore University Press.

. (2013). Semangat Baru: Kolonialisme, Budaya Cetak, dan Kesastraan Sunda Abad Ke-19 [A new spirit: Colonialism, Print Culture and Sundanese Literature in 19the century], Revised version, Jakarta: Komunitas Bambu, p. 340 .

(2017). "Jasa Balai Pustaka dalam Pembentukan Lierasi pada Abad ke20: Suatu Tinjauan dari Penerbitan Buku-buku berbahasa Sunda", in Koko Sudarmoko ed., Seratus Tahun 
Balai Pustaka (1917-2017), pp. 11-25, Jakarta: Balai Pustaka.

Rosidi, A.(1966). Kesusastran Sunda Dewasa Ini. Bandung: Tjupumanik.

(1982). Ikbtisar Sejarah Sastra Indonesia. ( $3^{\text {rd }}$ ed).Bandung: Binacipta.

.(1995). Puisi Sunda jilid 1. Bandung:

CV Geger Sunten.

(2000). 'Bahasa Indonesia, Bahasa

Kita', in J.B. Kristanto ed. Seribu

Tabun Nusantara, pp. 365-378, Jakarta:

Kompas.

Setiadi, H.F.(1991). 'Kolonialisme dan Budaya: Balai Poestaka di Hindia Belanda', Prisma 10.

Siregar, B. (1964). Sedjarah sastera Indonesia modern.Jakarta: Akademi Sastera dan Bahasa Multatuli.

Solomon, W.J.(1993). "The early Sundanese Novel, 1914-1940".Ph.D. thesis. Australian Naional University.

Teeuw, A.(1972). 'The impact of Balai Pustaka on modern Indonesian literature'.The Bulletin of the School of Oriental and African Studies, University of London 35(1): 111-127.

-(1986). Modern Indonesian Literature (2 vols). Dordrecht, Riverton: Foris Publication.

Uhlenbeck, E.M.(1964). A Critical Survey of Studies of the Language of Java and Madura. Gravenhage: Martinus Nijhoff.

Universitaire Biblioteken Leiden. (2014). Universitaire Biblioteken Leiden Jaarverslag 2014. Leiden.

\section{Notes:}

${ }^{1}$ This article was written for the The 1stInternational Conference on Language,
Literature, Culture and Education at Universitas Pendidikan Indonesia (Icollite), Bandung, West Java, Indonesia. The research was supported in part by a grant from JSPS (Kiban Kenkyu C) 2016-2020 year and a grant from Nanzan University Pache Research SubsidyI-A-2 for 2018. The data in this article is partly overlapped with the book of Moriyama (2005; 2013) because the research in this article is a continuation and developed discussion of the previous research. However, my argument in this article is quite different from the one in the previous book based on my further research on printed books after the establishment of the Committee for Indigenous Schoolbooks and Popular Reading Books in 1908. In particular, the discussion on the "disappearance of Wawacan” (Moriyama 2005: 201-205).

${ }^{2} \mathrm{My}$ research was mainly conducted on the collection of the library of Leiden University, united collection of the KITLV, Royal Institute of Linguistics and Anthropologylibrary (uniting the collections of the Koninklijk Institunt voor de Taal-, Land-en Volkenkunde van Nederland Indië and the Indisch Genootschap in The Hague), KIT, Royal Tropical Institute (Koninklijk Institunt voor de Tropen), and its own collection in terms of Indonesian books and periodicals (Universitaire Biblioteken Leiden 2014). And I added the collection from Perpustakaan Nasional in Jakarta and Perpustakaan Museum Konferensi Asia Afrika in Bandung.

${ }^{3}$ Newspapers and magazines in Sundanese were not included for the discussion in this article.

${ }^{4}$ My counting of printed books is not complete, but it seems that omissions are few because not many printing presses were available in the 19th century in the Dutch East Indies, especially in the Sundanese-speaking area. Most printing houses and publishers operated by Europeans/Eurasians, including missionaries, were registered by the government or documented elsewhere, and their publications were mostly collected in the library of the Bataviaasch Genootschap van Kunsten en Wetenschappen in Batavia. However, books printed and published by local printing houses including 
ones by lithograph printing were possibly escaped from my counting because no collection holds such productions.

${ }^{5}$ See more detail in Moriyama (2017).

${ }^{6}$ The printing houses that printed Sundanese books by order of the Volkslectuur were mostly Batavia-based companies. These included Ruygrok (established in 1910), Papyrus (est. 1910; formerly H.M. van Dorp \& Co., est. 1853), Indonesische Drukkerij (est. 1914), N.V. Elect. Drukk. Favoriet (est. 1915, Chinese-owned), Kantor Tjitak Javasche Boekhandel \& Drukkerij Batawi (est. 1896), Mercurius (est. 1907), J.B. Wolters' Uitgevers Maatschappij, Verwachting (est. 1915) and Kwee Khe Soei (est. c. 1926).

${ }^{7}$ This bookseller, Sie Dhian Ho, started a printing business in Solo in 1902. This was apparently a branch of the Bandung operation (Kitano 1993: 23).

${ }^{8}$ Javanese typography was developed in the 1820 s and 1830s and used in printing in various languages in the Dutch Indies (Molen 2000: 140149).

${ }^{9}$ For instance, Wawacan Panji Wulung in Roman script had only 122 pages, while the Javanese script version had 266.

${ }^{10}$ This book was translated by Ahmad Djajadiningrat, who was the most credible indigenous high official.

${ }^{11}$ Next to an expanding readership for printed materials, a readership of manuscripts remained until long after Independence. Even in the 1980s and 1990s, I came across villagers who read manuscripts at certain rituals.

${ }^{12}$ In the Malay case, a professional author in Batavia, Muhammad Bakir, had 76 titles of manuscripts for rent in the late 19th century, while printed books were also being read (Chambert-Loir 1991). This provides a good example of the overlapping readership.
13Please refer in detail to the chapter 3 in Moriyama (2005: 100-142).

${ }^{14}$ The word diilo is still used in the meaning of 'read by heart' (maca ku hate) (Satjadibrata 1954: 156). Eringa repeats Coolsma's interpretation, 'read by oneself' (voor zichzelf lezen) (Eringa 1984: 309).

${ }^{15}$ The book was published that same year in two volumes of 63 and 48 pages each by a large private printing house, G. Kolff \& Co. in Weltevreden, as number 90 in the series of the Committee for Indigenous Schoolbooks and Popular Reading Books.

${ }^{16}$ Karatani points out that one of the important moment to start for the modern literature is discovering inner self which is identical with modern self (Karatani 1993: 61-65).

${ }^{17}$ The magazine Parabiangan was published for the first time in 1929 by Balai Poestaka, a governmentsponsored institution in Batavia.

18S. Djojopoespito is famous for her Dutch novel Buiten het gareel (A life free from trammels) of 1940 (later translated into Indonesian by the author as Manusia Bebas or 'Free People' in 1975). She wrote her first novel in Sundanese; Marjanah was probably written in 1937.

${ }^{19}$ The first two wawacan were published by Toko Boekoe M.I. Prawira-Winata in Bandung.

${ }^{20}$ Wendy Solomon concluded that realistic wawacan could be regarded as novels, roman anu didangdingkeun (Solomon 1993: 12). However, it remains to be seen whether the Sundanese term 'roman' is equivalent to the English term 'novel'.

${ }^{21}$ The term 'basa diladjoer' (free compositon) was merant prose.

22The writer consciously uses the word basa diladjoer (free and open utterance) (Coolsma 1913: 317), denoting prose. He said elsewhere that Sundanese literature consisted of three forms of writing: wawacan, basa diladjoer, and poetry (Goeroe 1926: 14). Later on, Ajip Rosidi was to 
call prose basa lancaran (smooth words) (Rosidi 1995: 3). The term 'prosa' is most common nowadays.

23 Wawacan or books composed in dangding are occasionally published even today, but are limited to the use of a small circle of people who love singing tembang.

${ }^{24}$ This argument was inspired by the origin of modern Japanese literature written by Kojin Karatani (1993: 17-22). 